\title{
Mineralogy and Pollution Status of Columbite-Tin Ore Contaminated Soil
}

\author{
Adams Udoji Itodo (D) *, Raymond Ahulle Wuana, Bulus Emmanuel Duwongs, Davoe \\ Danbok Bwede
}

\begin{abstract}
A R T I C L E I N F O
Received: 16 January 2019

Revised: 27 January 2019

Accepted: 28 January 2019

Available online: 9 February 2019

\section{K E Y W O R D S}

Pollution Index

Geo-Accumulation

Mineral

Soil

Columbite

Tin

Plateau

A B S T R A C T

Mining activities are one of the numerous ways by which man impacts on his environment. In this study, two non-destructive analytical techniques (XRF and XRD) were employed in the mineralogical characterization of Columbite-Tin ore and their contaminated soils. This investigates associated unnoticed minerals as well as the impact of mining on vicinity farmland soils on the Yelwa-Mbar mining site, Nigeria. The chemical characterization of Columbite ore using electron dispersive XRF revealed that most of the Columbite mineral deposits in the Plateau mining sites contain Niobium mineral in various proportions and vary from deposit to deposit depending on the geochemical composition of the minerals that formed the parent rock. Tin content as determined by ED-XRF impart that the ore can be utilized directly in the furnace because of its high cassiterite content (85.43\%). The percentage elemental composition of soil around the mining vicinity unveiled the presence of Radionuclides K-40, Rubidium and Thorium in the soil. This is of great concern. The XRD mineralogical investigation of Columbite shows the presence of associated braunite, cassiterite, ilmenite, quartz, and zircon while the phase pattern for Tin ore confirmed the availability of cassiterite, magnetite and litharge. Pollution status based on contamination factor and geo-accumulation indices gave both radionuclides and heavy metal concentrations that depicts moderate to extreme contaminations.
\end{abstract}

\section{GRA P H ICAL ABST RACT}

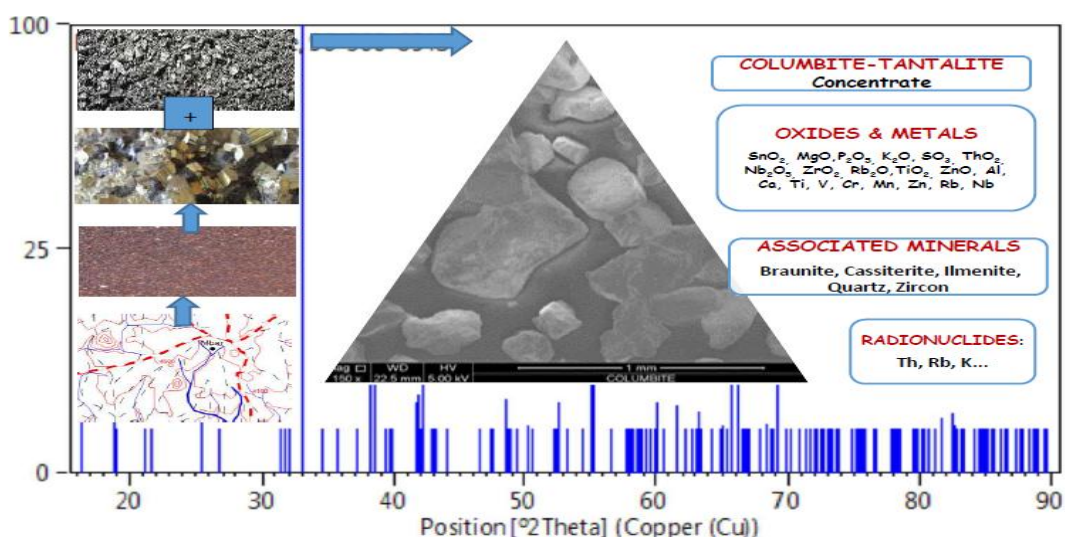

* Corresponding author's E-mail address: itodoson2002@gmail.com, Tel.: +02348039503463

Department of Chemistry, Federal University of Agriculture, PMB 2373 Makurdi, Nigeria. 


\section{Introduction}

One of the ways by which man impacts on his environment (both natural and built) is through mining activities [1]. Mining in Nigeria started as far back as the eighteenth century. Over 500 occurrences and deposits of over different minerals are known so far to exist within the country with the exploration of some of them being on a small scale [2]. The mining industry generates wastes which contain high concentrations of metals and metalloids which contaminates agricultural soils, air and water. These pollutants can be mobilized, resulting in leaching into ground and surface water. Most of these heavy metals are highly toxic and are not biodegradable [3].

In Jos, Plateau State, Tin and allied metals mining started about 1902 . Within this span of time the tin fields have been subjected to a process of unregulated mining activity, thereby devastate and depleted agricultural lands by intensive and extensive mechanized mining activities [4]. The early tin miners often overlooked the minerals of Niobium and Tantalum or had a great difficulty in separating them from the tin. Consequently, all cassiterite concentrates were contaminated with columbite-tantalite [4].

The contamination of agricultural soils and depletion of the environment as a result of unregulated mining activities poses threats to the environment and human. This research focus on the mineral characterization of Tin-Columbite contaminated soil. The study also investigates dearth information on the classes of contaminants and the compounds that are unearthed as a result of mining activities.

\section{Sample Location and Site Description}

Yelwa-Mbar (Figure 1) is in Bokkos local government of Plateau State Nigeria. Plateau state (latitudes $951^{\prime} 30^{\prime} \mathrm{N} ; 10^{\circ} 02^{\prime} 00^{\prime \prime} \mathrm{N}$ and longitudes 8 48'00"E; $95^{\prime} 00^{\prime \prime} \mathrm{E}$ ) is located in Nigeria's middle belt, with an area of $30,913 \mathrm{~km}^{2}(11,936 \mathrm{sq} \mathrm{m})$.

The state has an estimated population of about three million people. Named after the picturesque Jos, Plateau is a mountainous area in the north central of the state with captivating rock formations. Bare rocks are scattered across the grasslands, which cover the Plateau. The altitude ranges from around 1,200 meters (about 400 feet) to a peak of 1,829 meters above sea level in the Shere Hills range near Jos the state capital. It was noted [5] that plutonic and volcanic rocks predominate in the Jos Plateau, with some alluvium and other unconsolidated deposits. Years of tin mining have also left the area strewn with deep gorges and lakes. 


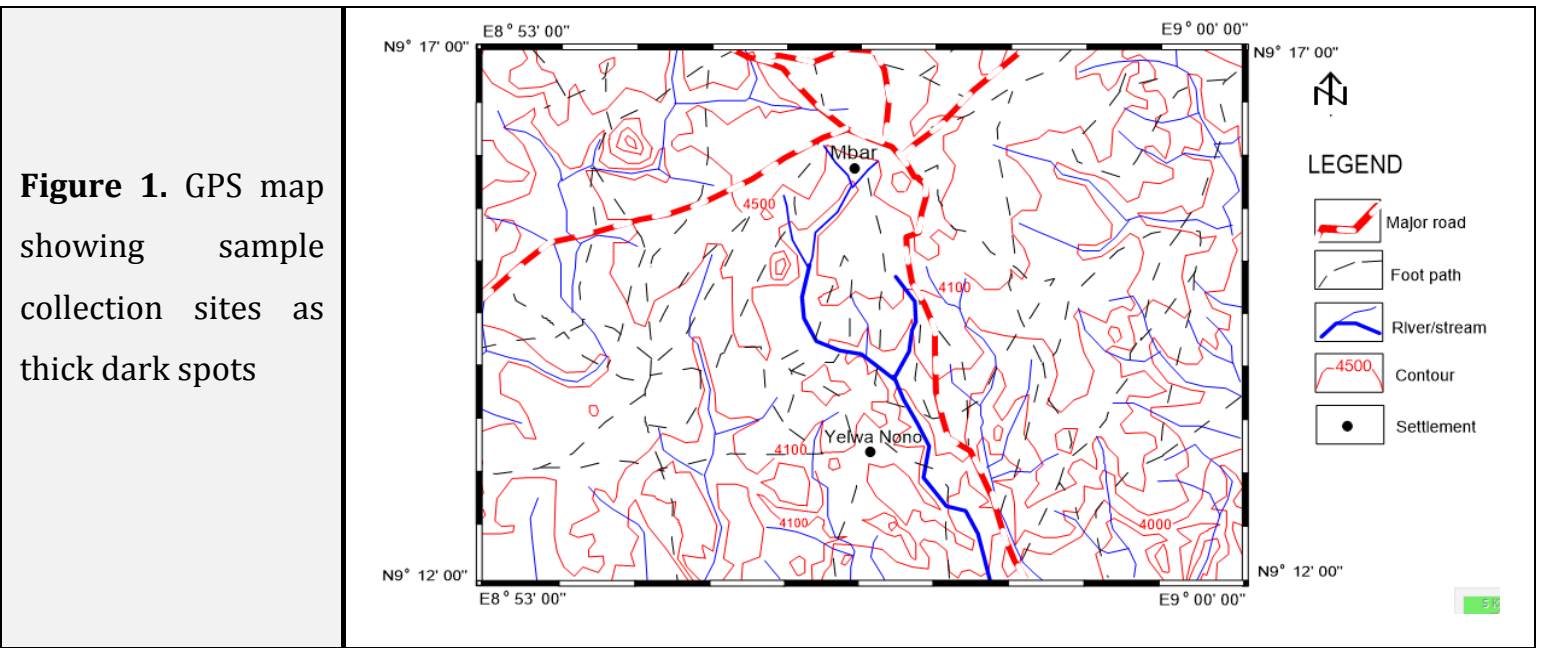

\section{Materials and methods}

Employed for this work are Energy Dispersive X-ray fluorescence spectrometer (MiniPAL4 ED-XRF), Scanning Electron Microscope (MVE016477830 SEM), X-Ray Diffraction (Empyrean XRD), and Fourier Transform Infra-red Spectrophotometer (Agilent tech. Cary 360 FTIR).

\section{Sampling}

Following documented protocol [6], $3 \mathrm{~kg}$ of the mineral ore samples were collected from 3 different pits and locations of the Yelwa Nono-Mbar, Bokkos mining sites of Plateau State. Samples were pretreated through washing, drying and grinding to particle size of $2 \mathrm{~mm}$ to distinguish between small and large particles. Agricultural soil samples were collected from mineral deposit vicinity (10-100 m) while samples for control experiment was collected from neighboring locations (300 - $500 \mathrm{~m})$, from non-mine sites. The mineral and soil samples were identified at the National Metallurgical Development Center (NMDC) Jos, plateau state.

\section{Physicochemical parameters of soil}

Physiochemical parameters of the soil samples, including $\mathrm{pH}$, conductivity and bulk density were carried out using documented standard laboratory procedures [7].

\section{Ore characterization}

SEM Analysis: SEM Phenomenon Prix model MVE016477830 was used for this analysis. Columbite and Tin samples were prepared using epoxy resins, polished and made conductive by carbon coating in a Dentom vacuum, DV-502A. The morphology of the Columbite and Tin ores were analyzed at an accelerating voltage of $20 \mathrm{KVA}$, real time of 21-36 and lifetime of 60 seconds. Images were made using the back scattering, electron detectors. 
FTIR Analysis: The functional groups present in the Columbite and Tin ore samples were investigated using the furrier transform infra-red spectrometer. The mineral samples were ground and sieved employing a US standard test sieve with an ASTM E-11 speciation. Fourier Transform Infra-red Spectrometer (Agilent technologies Cary 360) was used for this analysis.

Energy Dispersive X-Ray Fluorescence Analysis: The EDXRF characterization methods based on the instruction manual and practiced by the National Metallurgical Development Centre NMDC was adopted. Optimum Efficiency Dry High-Intensity Magnetic Separator (Three Disc Rapid Magnetic Separator; 4-3-15 OG) was used in Beneficiating the Columbite and Tin ores respectively. $20.00 \mathrm{~g}$ of the ore samples was finely ground (beneficiated) to pass through a 200-250 mesh sieve. Depending on the nature of the sample, it was dried in an oven at $105 \mathrm{C}$ for at least $1 \mathrm{~h}$ and allowed to cool. The sample was intimately mixed with a binder in the ratio of $5.0 \mathrm{~g}$ sample(s) to $1.0 \mathrm{~g}$ cellulose flakes binder and palletized at a pressure of 10-15 tons/inch ${ }^{2}$ in a pelletizing machine. At this stage the palletized sample(s) was stored in a desiccator for analysis. The ED-XRF (MiniPAL 4) was used to investigate the chemical composition of the soil, columbite and tin ore sample.

\section{Soil pollution indices}

Levels of pollution and degree of contamination was investigated using the Geo accumulation index and the contamination factor respectively. From eqn. $1, \mathrm{Bn}$ is the average geochemical background values for each metal in columbite and tin samples, $\mathrm{Cm}$ is the percentage element in the oxide (measured total concentration of metals in soils) for agricultural soil samples around mining site and 1.5 is the background matrix correction factor due to lithogenic effects [8]. The geoaccumulation index (Igeo) is used to determine the level of soil contamination (Table 1). The Igeo for heavy metal is calculated from base 2 logarithm of the measured total concentration of the metal over its background concentration as Eqn. (1):

$I_{g e o}=\log _{2}(\mathrm{Cm} / 1.5 \mathrm{Bn})$

Analytical results were subjected to prescribed pollution indices. Contamination factor (CF) is channeled towards deriving a realistic estimate of the amount of contamination that impacts on the soil [10]. Modified degree of contamination (mCd) is used to calculate the degree of contamination of metals in soils [11]. It is given as Eqn. (2).

$$
m C_{d}=\frac{1}{N} \sum_{i=1}^{N} C F_{i}
$$


Table 1. Muller classification for geo-accumulation index [9]

\begin{tabular}{ccc}
\hline Igeo & Class & Pollution status \\
\hline$>5$ & 6 & Extremely contaminated \\
$4-5$ & 5 & Heavy to extremely contaminated \\
$3-4$ & 4 & Heavily contaminated \\
$2-3$ & 3 & Moderately to heavily contaminated \\
$1-2$ & 2 & Moderately polluted \\
$0-1$ & 1 & Uncontaminated to moderately contaminated \\
0 & 0 & Practically uncontaminated \\
\hline
\end{tabular}

Where $N$ is the number of elements to be analyzed and $C F$ is the contamination factor calculated as shown in Eqn. (3).

$$
C F=\frac{C_{m} \text { Sample }}{C_{m} \text { Background }}
$$

\section{X-ray diffraction (XRD) analysis}

XRD analysis was carried out at the National Geoscience Research Laboratory (NGRL) Kaduna, Nigeria. The ores were exposed to air, allowed to dry and ground using a mechanical crusher. This was followed by sieving using sieve sizes ASTM $850 \mu \mathrm{m}, 425$ $\mu \mathrm{m}$ and $212 \mu \mathrm{m}$. Analysis of the samples was performed using Pan analytical (Empyrean model) X-ray diffraction machine. The samples were placed in a Lucite holder on the goniometer of the Scintag XDS 2000 powder diffractometer. It was also configured with a graphite monochromator and IBM compatible workstation running Scintag DMSNT software in a window NT environment. The diffraction beam monochromator operated at $20 \mathrm{KVA}$ with step size of $0.02^{\circ}$ for 120 minutes to create $\mathrm{x}$ - ray patterns with enough intensities so as to produce lines to identify minerals at the angles $\left(5^{0}-100^{\circ}\right)$. The scanning rate was $0.75^{0}$ per minute. Minerals were identified using the JCPDFWIN software. Peak analysis was also carried out using the Gaussian curve fitting. A continuous scan mode was used to collect $2 \theta$ data between $5.00^{\circ}$ to $100^{\circ}$ and the crystalline size was computed using the Debye-Scherrer equation given as Eqn. (4).

$\mathrm{D}=\mathrm{K} \lambda / \beta \operatorname{Cos} \theta$

$\mathrm{D}$ is the mean ore diameter (Particle size), $\mathrm{K}$ is a constant with value $0.9, \lambda$ is the wavelength of X-ray (1.540598), $\beta$ is full width at half maximum and $\theta$ is the differential angle [12].

\section{Results and discussion}

\section{Physical inspection of samples}

Figure 2 is a pictorial representation of sampling site and ore samples.

Mining vicinity was predominantly contaminated with mining waste called tailings. 


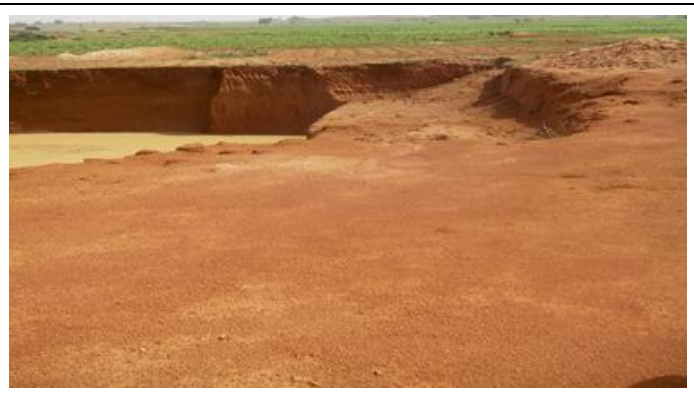

(A)

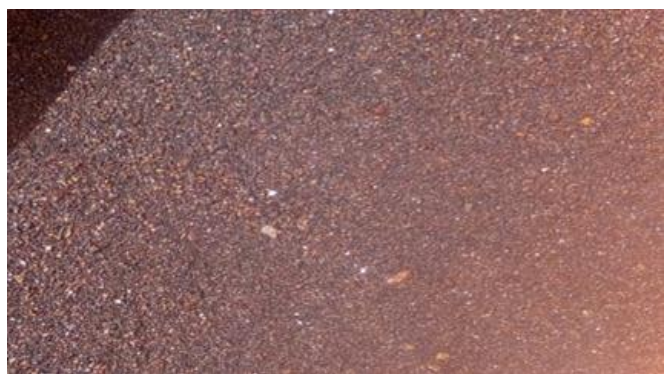

(B)

Figure 2. Pictorial representation of Columbite -Tin mine site within farmland soil (LHS) and ore from study area (LHS)

The surrounding agricultural soil shows high tendency to leaching and erosion due to consistent mining activities and this was observed to have adverse effects on agricultural plants such as plants leaves coloration, Generally, the contamination of soils associated with mining operations by radionuclides and heavy metals leads to negative effect or influence on the soil characteristics and this limits production and environmental functions. Tailings have been found to contain high activity concentrations of ${ }^{238} \mathrm{U}$ and ${ }^{232} \mathrm{Th}$ and this could result in internal exposure of the entire living population through leaching activity which may be directly ingested through drinking water or may indirectly enter the food chain by uptake through vegetation, fish, milk and meat [3].

\section{Physiochemical parameters of soil samples}

Physiochemical parameters $\mathrm{pH}$, conductivity and bulk density of agricultural soil samples around mine and control sites were quantified as $4.95,0.05(\mu \mathrm{S} / \mathrm{cm})$ and $1.30 \quad\left(\mathrm{~g} / \mathrm{cm}^{3}\right) \quad$ respectively. Their corresponding values for experimental control soil are 3.305, $0.035(\mu \mathrm{S} / \mathrm{cm})$ and $1.246\left(\mathrm{~g} / \mathrm{cm}^{3}\right)$.

pH: pH range of 3.3-5.0 was observed for agricultural soil samples. These $\mathrm{pH}$ values were lower than those observed in plants. Below pH 5.5, low legume and forage growth occur due to metal toxicities such as aluminum or manganese, phosphorus fixation, and reduced population of $\mathrm{N}$-fixing bacteria. This growth, hence inhibits plant root growth and many other metabolic processes [14]. This result shows that $\mathrm{pH}$ of both sides was within the acidic range. Slightly higher value for the analytical soil sample could be linked to mining activities.

Bulk density: The density of the control sample $\left(1.246 \mathrm{~g} / \mathrm{cm}^{3}\right)$ is lower compared to that of the analytical soil sample estimated at $1.30 \mathrm{~g} / \mathrm{cm}^{3}$. This could result from 
repeated traffic of wheeled mining machineries (loaders and haulers) forming compacted zones in the mining dumps. Report [15] shows that these values were slightly higher in clay soil. Generally, the bulk density of productive natural soils is 1.1 $\mathrm{g} / \mathrm{cm}^{3}$. High bulk density limits rooting depth in mine soils [16].

Conductivity: The mean conductivity value of the analytical soil sample $(0.07 \mu \mathrm{S} / \mathrm{cm})$ and a control sample $(0.05 \mu S / \mathrm{cm})$ are generally llow. This may be linked to low level electrical potential in soils; clays and other water saturated and unsaturated sediments, few ionic layers, electro filtration, $\mathrm{pH}$ difference and electro osmosis [17].

\section{SEM characterization of mineral ore}

Figure 3 shows the morphological characteristics of the particles in the columbite and tin ores determined by SEM technique.

The surface morphology of the Tin and
Columbite ores were examined using the scanning electron microscopy. It was earlier reported that cassiterite is the main ore mineral of tin occurring in the quartz veins of the plateau mining sites [18].

Investigating the surface morphology of the ore sample revealed a compact interlocking of these minerals within the irregular crystal aggregate of the ore sample. Figure 2 shows the typical SEM morphology of samples appearing in different sizes with irregular shapes showing compact aggregates at $150 \mathrm{x}$ magnification. Previous studies on nanocrystalline $\mathrm{SnO}_{2}$ have shown that pure metastable tetragonal phase can be stabilized when the crystal size is below a critical size [19]. SEM assist in ore characterization and predictive metallurgy [18].

\section{FTIR spectral characteristics}

Spectral profile characteristics of each mineral samples (Figure 4) and their interpretation (Table 2) were presented.

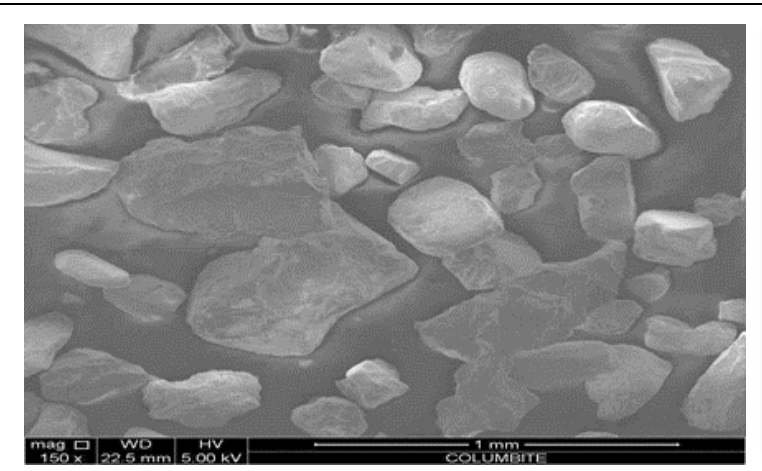

(A)

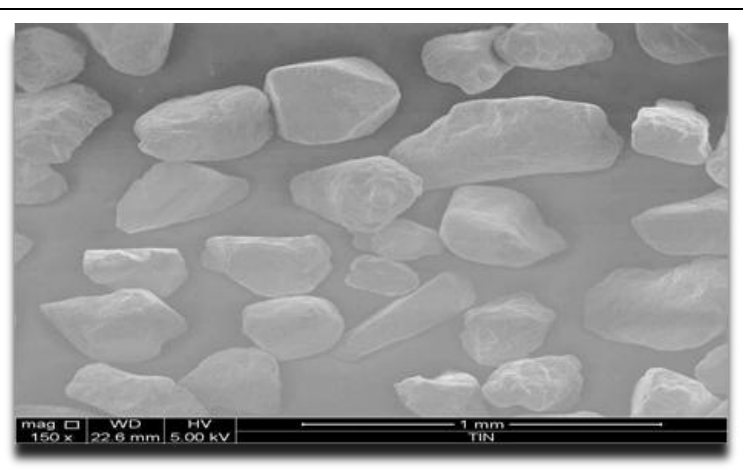

(B)

Figure 3. SEM images of (a) Columbite and (b) Tin ores 


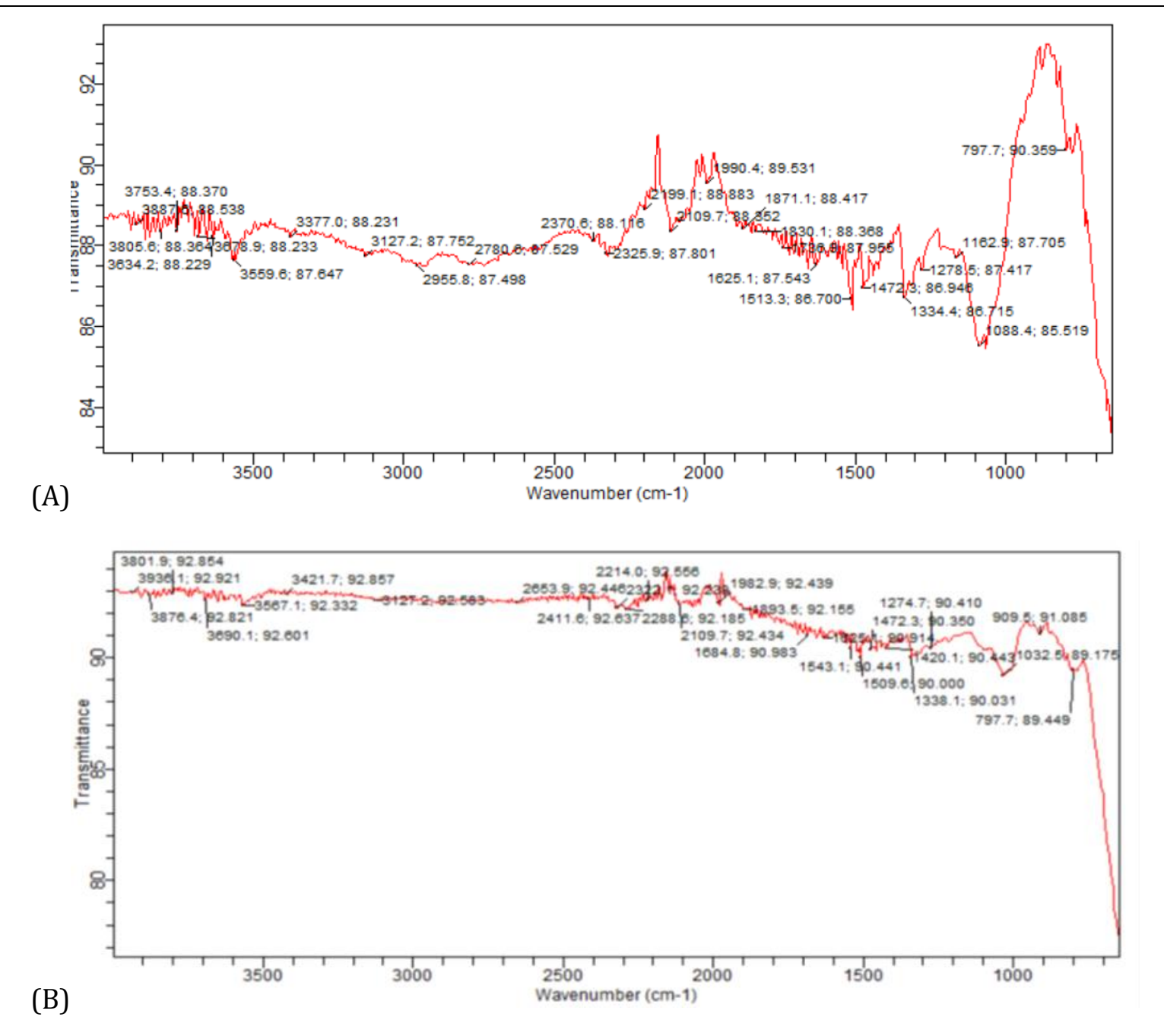

Figure 4. FTIR spectrum of Columbite (a) and Tin (b) ores

Table 2. FTIR spectral information of Columbite and Tin ore samples

\begin{tabular}{|c|c|c|c|c|}
\hline \multirow{2}{*}{$\begin{array}{l}\text { Group freq. } \\
\left(\mathrm{cm}^{-1}\right)\end{array}$} & \multirow{2}{*}{$\begin{array}{l}\text { Functional } \\
\text { group }\end{array}$} & \multicolumn{2}{|c|}{ Observed frequency $\left(\mathrm{cm}^{-1}\right)$} & \multirow[t]{2}{*}{ Assignment } \\
\hline & & Columbite ore & Tin ore & \\
\hline 797.7 & $\mathrm{Ag}^{+}$ & 797.7 & 797.7 & Silver bromate \\
\hline $1100-1000$ & $\mathrm{Ca}^{2+}, \mathrm{Mg}^{2+}$ & 1088.4 & - & $\begin{array}{l}\text { Calcium phosphate and } \\
\text { magnesium metaborate }\end{array}$ \\
\hline $1328-2380$ & $\mathrm{Na}^{+}$ & 1334.4 & 1338.1 & $\begin{array}{c}\text { Sodium nitrate and related } \\
\text { nitrate ions }\end{array}$ \\
\hline $1430-1640$ & $\mathrm{Ca}^{2+}, \mathrm{CO}_{3}^{2-}$ & 1472.3 & 1543.1 & $\begin{array}{l}\text { Calcium nitrate and } \\
\text { carbonates }\end{array}$ \\
\hline $1560-1540$ & $\mathrm{PO}_{4}^{3-}$ & 1513.3 & 1509.6 & $\begin{array}{l}\text { Calcium nitrate and } \\
\text { carbonates }\end{array}$ \\
\hline $\begin{array}{c}1555- \\
1485 / 1355- \\
1320\end{array}$ & $\mathrm{NO}^{3-}$ & 1162.9 & - & Cyclic nitro compounds \\
\hline $2000-2200$ & $\mathrm{CN}^{-}, \mathrm{SCN}^{-}$ & 2325.9 & 2109.7 & $\begin{array}{l}\text { Cyanide ion, thiocyanide and } \\
\text { related ions }\end{array}$ \\
\hline
\end{tabular}


The Fourier Transform Infrared (FTIR) Spectroscopy is an alternative method for acquiring quantitative and functional groups of mineral compounds [20]. From Figure 4. The absorption band range of 797.7 to $2200 \mathrm{~cm}^{-1}$ reveals the presence of compounds of Calcium phosphates and Magnesium metaborate, Silver bromate, Sodium nitrates, Calcium nitrates and Carbonates (Table 2). The carbonates spectra are characterized by strong absorption bands due to internal vibrational modes of the $\mathrm{CO}_{3}{ }^{2-}$ groups [21]. The bands around $2935 \mathrm{~cm}^{-1}$ related to the total carbon present on the cell surface increased permanently. The spectra also revealed at the beginning of the process, for all tests, an increased number of anglesite and scontlandite bands [22]. The absorption bands reveal that Silver bromate, Nitrate ion, Ammonium phosphates and aliphatic Nitro compounds, Cyanides and Thiocyanide ions were present in the tin mineral ore, which are believed to be from the parent rock that form the surrounding soil [23].

\section{X-ray fluorescence characterization of} Columbite ore

Findings show that oxides of Silicon, Titanium, Chromium, Manganese, Iron and Zirconium have preferentially high percentage in Columbite sample compared to Tin sample. Oxides of Aluminum, Nickel, Zinc, Hafnium and Lead are detected in Columbite sample and were not detected in Tin sample. In the same vain, oxides of phosphorus and tungsten were detected only in Tin sample, while those of Silver, Bismuth and Thorium recovery were low in percentage for both Tin and Columbite samples. Table 3 presents the results of the chemical analysis of the columbite ore sample using electron dispersive XRF. The result revealed that the ore sample contained $2.20 \% \mathrm{Al}_{2} \mathrm{O}_{3}, 21.7 \% \mathrm{SiO}_{2}, 19.59 \%$ $\mathrm{TiO}_{2}, 0.50 \% \mathrm{~V}_{2} \mathrm{O}_{5}, 0.58 \% \mathrm{Cr}_{2} \mathrm{O}_{3}, 0.78 \% \mathrm{MnO}$, $26.73 \% \mathrm{Fe}_{2} \mathrm{O}_{3}, 0.11 \% \mathrm{ZnO}, 0.93 \% \mathrm{Nb}_{2} \mathrm{O}_{5}$, $0.17 \% \quad \mathrm{Ta}_{2} \mathrm{O}_{5}, \quad 0.83 \% \mathrm{SnO}_{2}, \quad 0.49 \% \quad \mathrm{Ag}_{2} \mathrm{O}$, $0.51 \% \mathrm{HfO}_{2}, 0.27 \% \mathrm{ThO}_{2}, 12.9 \% \mathrm{ZrO}_{2}$ and few of $0.05 \% \mathrm{CaO}, 0.07 \% \mathrm{NiO}, 0.09 \% \mathrm{PbO}$ and $0.07 \% \mathrm{Bi}_{2} \mathrm{O}_{3}$. Most of the Columbite mineral deposits in the Plateau mining sites are found to contain Niobium mineral. Available mineral depends on the geochemical composition of the minerals that formed the parent rock of the area [23]. This result also indicated that the ore cannot be utilized directly because of its low Niobium content unless it is beneficiated to meet metallurgical required grade. Thorium has a long half-life of $0.4 \times 10^{10}$ years. It is used for making ceramics, welding rods, camera and telescope lenses, fire brick, heat 
resistant paint, and metals used in the aerospace industry as well as a nuclear fuel [24]. It is evidence that breathing in thorium dust increases the risk of lungs and pancreatic cancer. Exposure to it also causes bone cancer because thorium can be stored in bone [25].

\section{X-ray fluorescence characterization of tin ore}

The result of the chemical analysis of the tin ore sample using ED - XRF as presented in Table 3 revealed that the ore sample contained $1.00 \% \mathrm{SiO}_{2}, 0.63 \% \mathrm{P}_{2} \mathrm{O}_{5}, 2.86 \%$ cap, $2.03 \% \mathrm{TiO}_{2}, 0.32 \% \mathrm{~V}_{2} \mathrm{O}_{5}, 0.25 \% \mathrm{Cr}_{2} \mathrm{O}_{3}$, $0.10 \% \mathrm{MnO}, 2.35 \% \mathrm{Fe}_{2} \mathrm{O}_{3}, 1.85 \% \mathrm{Nb}_{2} \mathrm{O}_{5}$, $0.49 \% \mathrm{Ta}_{2} \mathrm{O}_{5}, \quad 85.43 \% \mathrm{SnO}_{2}, \quad 0.17 \% \mathrm{WO}_{3}$, $0.16 \% \mathrm{ThO}_{2}, 0.85 \% \mathrm{ZrO}_{2}$, and low recovery percentages of $0.04 \% \mathrm{Ag}_{2} \mathrm{O}, 0.008 \% \mathrm{Bi}_{2} \mathrm{O}_{3}$. The tin ore can be utilized directly in the furnace because of its high cassiterite (tin) content varying between deposit to deposit in the plateau mining sites.

\section{Chemical composition of agricultural soil} around mine site

$\mathrm{XRF}$ analysis was used to determine the chemical and percentage elemental composition of agricultural soil around mine site. This was presented in Table 3 revealing $12.40 \% \mathrm{Al}_{2} \mathrm{O}_{3}, 53.70 \% \mathrm{SiO}_{2}, 0.08 \% \mathrm{P}_{2} \mathrm{O}_{5}$, $0.60 \% \mathrm{~K}_{2} \mathrm{O}, 0.38 \% \mathrm{CaO}, 4.10 \% \mathrm{TiO}_{2}, 0.16 \%$ $\mathrm{V}_{2} \mathrm{O}_{5}, \quad 0.31 \% \mathrm{CrO}_{3}, \quad 0.17 \% \mathrm{MnO}, 18.22 \%$ $\mathrm{Fe}_{2} \mathrm{O}_{3}, 0.01 \% \mathrm{NiO}, 0.04 \% \mathrm{CuO}, 0.03 \% \mathrm{ZnO}$,
$0.02 \% \quad \mathrm{Rb}_{2} \mathrm{O}, \quad 2.60 \% \quad \mathrm{ZrO}_{2}, \quad 0.37 \% \quad \mathrm{Nb}_{2} \mathrm{O}_{5}$, $0.11 \% \mathrm{ThO}_{2}$ and $0.03 \% \mathrm{Au}$ were present in the sample. Concentrations of oxides of phosphorus, nickel and zinc are with contamination factor values of $0.18-1.0 \mathrm{mM}$, hence nontoxic [26]. However, Seeing the reoccurring hazards from mines across the Plateau state and other risks in the sector through inland sand mining and the effects of artisanal mining, the concentration of toxic residues, geological hazards and ecological disturbances and destruction of flora and fauna are major challenges from mining [27].

Results from Table 4 reveals that the oxides of Titanium, Iron, zirconium, Aluminum and silicon appears to be the most predominant oxides in both mineral ore samples and the mine site agricultural soil sample. Radionuclides such as potassium (K-40), Rubidium and Thorium were also present in the soil. The contamination of soils by radionuclides and heavy metals leads to a negative influence on soil characteristics and limits production and environmental functions. Thorium and phosphorus were not detected in the control sample. From this analysis, heavy metals and radioactive nuclides such as $\mathrm{Al}, \mathrm{Ca}, \mathrm{Ti}, \mathrm{V}, \mathrm{Cr}, \mathrm{Mn}, \mathrm{Fe}, \mathrm{Ni}$, $\mathrm{Cu}, \mathrm{Zn}, \mathrm{Rb}, \mathrm{Nb}$, and gold appears in very low concentrations compared to samples of agricultural soils around mining sites. These heavy metals are phytotoxic either at all 
concentrations or above certain threshold levels [28].

Table 3. XRF result showing chemical composition of ores

\begin{tabular}{|c|c|c|c|c|c|c|}
\hline \multirow{2}{*}{$\begin{array}{l}\text { S/No } \\
1 .\end{array}$} & \multirow{2}{*}{$\begin{array}{c}\text { Oxide } \\
\mathrm{Al}_{2} \mathrm{O}_{3}\end{array}$} & \multicolumn{2}{|c|}{$\begin{array}{l}\text { Composition of Oxide } \\
\text { Columbite (\%) Tin (\%) }\end{array}$} & \multirow{2}{*}{$\begin{array}{c}\text { Element } \\
\text { Aluminum }\end{array}$} & \multicolumn{2}{|c|}{$\begin{array}{c}\text { \% element in oxide } \\
\text { Columbite }(\%) \text { Tin }(\%)\end{array}$} \\
\hline & & 2.20 & ND & & 8.154 & NA \\
\hline 2. & $\mathrm{SiO}_{2}$ & 21.7 & 1.00 & Silicon & 77.5 & 3.560 \\
\hline 3. & $\mathrm{P}_{2} \mathrm{O}_{5}$ & ND & 0.63 & Phosphorus & NA & 2.034 \\
\hline 4. & $\mathrm{~K}_{2} \mathrm{O}$ & ND & ND & Potassium & NA & NA \\
\hline 5. & $\mathrm{CaO}$ & 0.05 & 2.86 & Calcium & 0.125 & 7.150 \\
\hline 6. & SO3 & ND & ND & Sulphur & NA & NA \\
\hline 7. & $\mathrm{TiO}_{2}$ & 19.59 & 2.03 & Titanium & 40.89 & 4.238 \\
\hline 8. & $\mathrm{~V}_{2} \mathrm{O}_{5}$ & 0.50 & 0.32 & Vanadium & 0.982 & 0.628 \\
\hline 9. & $\mathrm{Cr}_{2} \mathrm{O}_{3}$ & 0.58 & 0.25 & Chromium & 1.115 & 0.480 \\
\hline 10. & $\mathrm{MnO}$ & 0.78 & 0.10 & Manganese & 1.419 & 0.182 \\
\hline 11. & $\mathrm{Fe}_{2} \mathrm{O}_{3}$ & 26.73 & 2.35 & Iron & 47.87 & 4.208 \\
\hline 12. & $\mathrm{NiO}$ & 0.007 & ND & Nickel & 0.012 & NA \\
\hline 13. & $\mathrm{CuO}$ & ND & ND & Copper & NA & NA \\
\hline 14. & $\mathrm{ZnO}$ & 0.11 & ND & Zinc & 0.168 & NA \\
\hline 15. & $\mathrm{Nb}_{2} \mathrm{O}_{5}$ & 0.93 & 1.85 & Niobium & 1.001 & 1.991 \\
\hline 16. & $\mathrm{Ta}_{2} \mathrm{O}_{5}$ & 0.17 & 0.49 & Tantalum & 0.094 & 0.270 \\
\hline 17. & $\mathrm{SnO}_{2}$ & 6.83 & 85.43 & Tin & 0.690 & 71.98 \\
\hline 18. & $\mathrm{WO}_{3}$ & ND & 0.17 & Tungsten & NA & 0.092 \\
\hline 19. & $\mathrm{Ag}_{2} \mathrm{O}$ & 0.49 & 0.04 & Silver & 0.454 & 0.037 \\
\hline 20. & $\mathrm{HfO}_{2}$ & 0.51 & ND & Hafnium & 0.286 & NA \\
\hline 21. & $\mathrm{PbO}$ & 0.09 & ND & Lead & 0.043 & NA \\
\hline 22. & $\mathrm{Bi}_{2} \mathrm{O}_{3}$ & 0.07 & 0.008 & Bismuth & 0.034 & 3.829 \\
\hline 23. & $\mathrm{ThO}_{2}$ & 0.27 & 0.16 & Thorium & 0.116 & 0.069 \\
\hline 24. & $\mathrm{ZrO}_{2}$ & 12.9 & 0.85 & Zircon & 14.14 & 0.932 \\
\hline
\end{tabular}

ND-Not Detected, NA-Not Applicable

Table 4. XRF showing chemical composition of soil from mining and control sites

\begin{tabular}{|c|c|c|c|c|c|c|}
\hline \multirow{2}{*}{$\begin{array}{l}\text { S/No } \\
1 .\end{array}$} & \multirow{2}{*}{$\begin{array}{l}\text { Oxide } \\
\mathrm{Al}_{2} \mathrm{O}_{3}\end{array}$} & \multicolumn{2}{|c|}{$\begin{array}{c}\text { \% Oxides in Soil } \\
\text { Mine site }(\%) \text { Control } \\
(\%)\end{array}$} & \multirow{2}{*}{$\begin{array}{l}\text { Element } \\
\text { Aluminum }\end{array}$} & \multicolumn{2}{|c|}{$\begin{array}{c}\text { \% element in Soil } \\
\text { Mine site }(\%) \text { Control } \\
(\%)\end{array}$} \\
\hline & & 12.40 & 5.50 & & 45.96 & 20.37 \\
\hline 2. & $\mathrm{SiO}_{2}$ & 53.70 & 78.98 & Silicon & 191.2 & 282.1 \\
\hline 3. & MgO & ND & ND & NA & NA & NA \\
\hline 4. & $\mathrm{P}_{2} \mathrm{O}_{5}$ & 0.08 & ND & Phosphorus & 0.258 & NA \\
\hline 5. & $\mathrm{SO}_{3}$ & ND & ND & NA & NA & NA \\
\hline 6. & $\mathrm{~K}_{2} \mathrm{O}$ & 0.60 & 0.82 & Potassium & 1.534 & 2.097 \\
\hline 7. & $\mathrm{CaO}$ & 0.38 & 0.09 & Calcium & 0.950 & 0.225 \\
\hline 8. & $\mathrm{TiO}_{2}$ & 4.10 & 1.04 & Titanium & 8.559 & 2.171 \\
\hline 9. & $\mathrm{~V}_{2} \mathrm{O}_{5}$ & 0.16 & 0.03 & Vanadium & 0.314 & 0.059 \\
\hline 10. & $\mathrm{CrO}_{3}$ & 0.31 & 0.12 & Chromium & 0.596 & 0.230 \\
\hline 11. & $\mathrm{MnO}$ & 0.17 & 0.07 & Manganese & 0.309 & 0.127 \\
\hline 12. & $\mathrm{Fe}_{2} \mathrm{O}_{3}$ & 18.22 & 4.80 & Iron & 32.62 & 8.595 \\
\hline 13. & $\mathrm{NiO}$ & 0.01 & 0.009 & Nickel & 0.017 & 0.015 \\
\hline 14. & $\mathrm{CuO}$ & 0.04 & 0.02 & Copper & 0.062 & 0.031 \\
\hline 15. & $\mathrm{ZnO}$ & 0.03 & 0.007 & Zinc & 0.046 & 0.011 \\
\hline 16. & $\mathrm{Rb}_{2} \mathrm{O}$ & 0.02 & 0.01 & Rubidium & 0.023 & 0.012 \\
\hline 17. & $\mathrm{ZrO}_{2}$ & 2.60 & 0.40 & Zircon & 2.850 & 0.439 \\
\hline 18. & $\mathrm{Nb}_{2} \mathrm{O}_{5}$ & 0.37 & 0.04 & Niobium & 0.398 & 0.043 \\
\hline 19. & $\mathrm{ThO}_{2}$ & 0.11 & ND & Thorium & 0.047 & NA \\
\hline 20. & $\mathrm{Au}$ & 0.03 & 0.02 & Gold & 0.015 & 0.010 \\
\hline
\end{tabular}


In the aquatic environment, these metallic elements or oxides gets into the streams through runoff of agricultural soils around mining sites existing in a number of different chemical forms (species), distributed between sediments and the solutions [29].

\section{XRD characterization of columbite-tin} mineral

Tables 5 present the crystallographic parameters of associated minerals and compounds in Columbite ore. Analysis was performed using X-ray diffraction technique. The diffractograms for compounds with Columbite ore are presented in Figure 5.

\section{Mineralogy of columbite ore}

The main minerals found in the Columbite sample were Braunite, Cassiterite, Ilmenite, Quartz, and Zircon. Each of these compounds has a phase information from the XRD pattern as shown in Figure 5 and Table 5. The diffraction of X-rays by the crystalline solid mineral sample results in a pattern of sharp Bragg reflections characteristic of the different d-spacing of the solid. Broadening of these reflections beyond that due to instrumental factors is generally attributed to crystallite size effects [30].

\section{Braunite in columbite}

This study revealed that the $2 \theta$ values of 32.982 and 55.317 shows high intensities (Table 6), and this is attributed to crystallite size effects. Braunite $\left(\mathrm{Mn}_{2} \mathrm{O}_{3} \cdot \mathrm{MnSiO}_{3}\right)$ compound aside its occurrence alongside Columbite mineral, also occurs in regionally metamorphosed manganese deposits such as gondites and kodurites [31]. The occurrence of irregular zones of braunite around sand grains in manganiferous clays suggested that it was a reaction product possibly produced from the sedimentation of $\mathrm{MnO}_{2}$ colloids.

\section{Cassiterite in columbite}

The $2 \theta$ values between $26.596,33.875$ and 51.785 reveals high intensities. Broadening of reflections beyond these values due to instrumental factors is attributed to crystallite size effects.

Table 5. Crystallographic parameters of columbite showing major compounds

\begin{tabular}{lcccccccc}
\hline S/No & Compounds & $\mathbf{a}(\AA)$ & $\mathbf{b}(\AA)$ & $\mathbf{c}(\AA)$ & $\begin{array}{c}\text { Alpha } \\
(\mathbf{0})\end{array}$ & Beta( $\mathbf{0})$ & $\begin{array}{c}\text { Gamma } \\
(\mathbf{0})\end{array}$ & $\begin{array}{c}\text { Crystal } \\
\text { system }\end{array}$ \\
\hline 1. & Braunite & 9.4270 & 9.4270 & 18.695 & 90.0 & 90.0 & 90.0 & Tetrahedral \\
2. & Cassiterite & 4.7360 & 4.7360 & 3.1870 & 90.0 & 90.0 & 90.0 & Tetrahedral \\
3. & Ilmenite & 5.0832 & 5.0832 & 14.026 & 90.0 & 90.0 & 120 & Hexagonal \\
4. & Quartz & 4.9120 & 4.9120 & 5.4040 & 90.0 & 90.0 & 120 & Hexagonal \\
5. & Zircon & 6.5930 & 6.5930 & 5.9740 & 90.0 & 90.0 & 90.0 & Tetragonal \\
\hline
\end{tabular}


(A)

Intensity [\%]

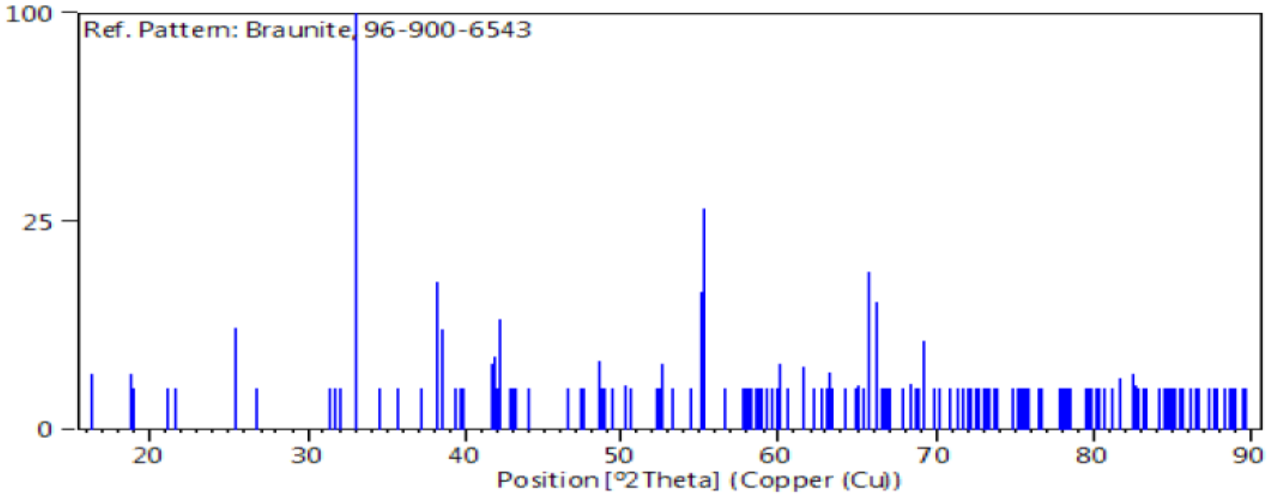

Intensity [\%]

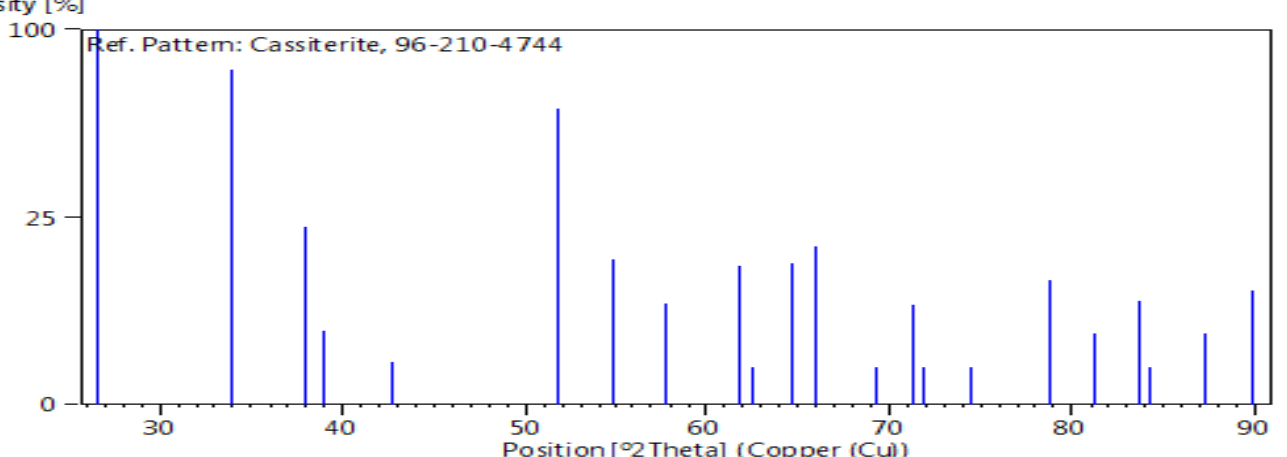

(B)

Intensity [\%]

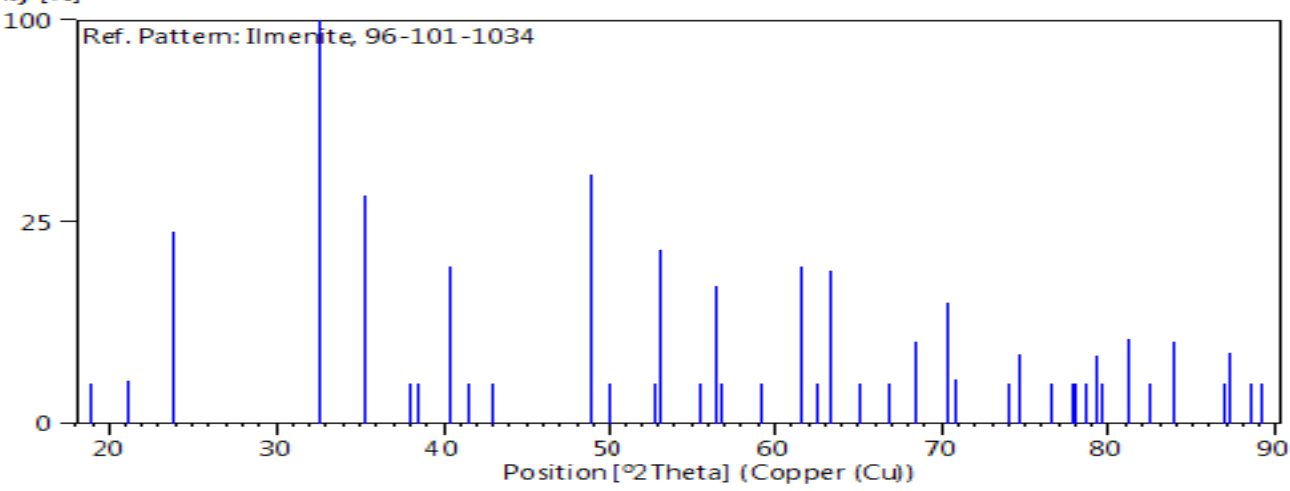

(C)

Intensity [\%]

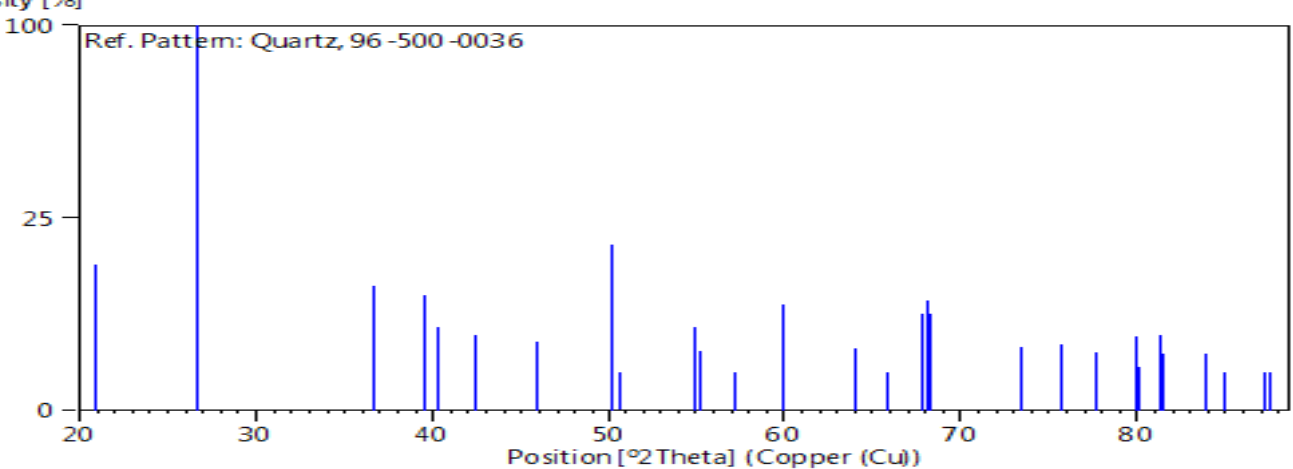

(D)

Figure 5. X-Ray diffractogram of (a) braunite (b) cassiterite (c) ilmenite and (d) quartz in columbite sample 
Cassiterite is a typical wide band gap n-type semiconductor (3.6 Ev) and one of the widely used semiconductor oxides due to its chemical and thermal stabilities. It is a nonstoichiometric structure, and its conductivity mainly originates from the oxygen vacancies [32]. The electrical and chemical properties of cassiterite have been extensively studied, and this is because of its application as transparent electrodes for solar cell, liquid crystal display, anti-static coatings and gas sensors, anode for lithium ion batteries, transistors and as catalyst support [33].

\section{Ilmenite in columbite}

The chemical analysis of the Ilmenite in Columbite sample shows high intensity for $2 \theta$ at 32.622. Broadening of reflection attributed to crystallite size is less. Ilmenite $\left(\mathrm{FeTiO}_{3}\right)$ is black and opaque with $\mathrm{TiO}_{2}$ contents between 45 and $65 \%$ usually occurring alongside other sand minerals such as tin and columbite. Because it is non-toxic, it is used in cosmetics and pharmaceuticals. About $6 \%$ is used to manufacture titanium metal, a light, strong, corrosion-resistant metal used in aircraft, spacecraft and medical prostheses. Its application in the process of fine grain materials aggregation or pelletizing cannot be over emphasized [34].

\section{Quartz in columbite}

Quartz has also revealed a single high intensity at $2 \theta$ value 23.647, other intensities reveal lower values below 25\% intensity. Broadening of these reflections beyond that due to instrumental factors is attributed to crystallite size effects. Quartz sand is the final product of rock weathering which is an important part of the rock cycle. On the Jos plateau, quartz is the major component of the abundant rock minerals in the state. The weathering of any quartz-bearing rock creates sand: igneous, sedimentary, or metamorphic rocks. Quartz is used in a great variety of products and the term "quartz sand" in its finest form, as micro-silica it is used as an essential raw material for the glass and foundry casting industries, as well as in other industries such as ceramics, chemical manufacture and for water filtration purposes.

\section{Zircon in columbite}

The result revealed that the $2 \theta$ values for Zircon (20.041, 27.027, 35.670 and 53.560) shows high intensities. This implies that broadening of reflections beyond $25 \%$ due to instrumental factors is predominant for zirconium in columbite sample and this is also attributed to crystallite size effects. Zircon (ZrSiO4); Zirconium silicate, often occurs with some hafnium (1 to $4 \%$.) and occasionally with solid minerals such as tin, uranium, Columbite, Hafnium, thorium, and yttrium [26]. Zircon sand is used in various range of industrial applications and in a variety of markets ranging from foundry molding sands to zirconium-metal manufacture. This analysis shows that zircon 
occurs alongside radioactive elements such as $\mathrm{U}$ and Th [25].

\section{Mineralogy of tin ore}

The mineralogy of the crushed Tin ore was carried out by X -ray diffraction technique. The main minerals found in the sample were Cassiterite, Litharge and Magnetite, with each of this compound having a phase information from the XRD pattern. In the plateau mining sites, Tin occurs naturally in the form of cassiterite with varying amounts of associated minerals [6]. The principal minerals of commercial interest are Titanium Minerals (rutile and Ilmenite), columbite (niobium and tantalum), Monazite, magnetite, litharge, and zircon. Cassiterite main

Table 6. XRD peak information of braunite in columbite sample

\begin{tabular}{lcccc}
\hline S/No. & d [̊̊] & 2 Theta [deg] & I [\%] & Crystalline size(nm) \\
\hline 1. & 3.49186 & 25.488 & 6.0 & 0.0171 \\
2. & 2.71363 & 32.982 & 100.0 & 0.0184 \\
3. & 2.35675 & 38.155 & 12.6 & 0.0196 \\
4. & 2.33687 & 38.492 & 5.8 & 0.0197 \\
5. & 2.14268 & 42.139 & 7.1 & 0.0208 \\
6. & 1.66647 & 55.063 & 11.0 & 0.0269 \\
7. & 1.65940 & 55.317 & 28.1 & 0.0271 \\
8. & 1.42007 & 65.699 & 14.5 & 0.0374 \\
9. & 1.41135 & 66.158 & 9.5 & 0.0381 \\
\hline
\end{tabular}

Table 7. Contamination factor $C_{f}$ of elements in columbite-tin soil

\begin{tabular}{ccccc}
\hline Class & Elements & Mine site & $\begin{array}{c}\text { \% Composition } \\
\text { Control }\end{array}$ & $\boldsymbol{C}_{\boldsymbol{f}}$ \\
\hline Heavy metals & Manganese & 0.309 & 0.127 & 2.433 \\
& Chromium & 0.596 & 0.230 & 2.591 \\
& Iron & 32.62 & 8.595 & 3.795 \\
& Titanium & 8.559 & 2.171 & 3.942 \\
& Vanadium & 0.314 & 0.059 & 5.322 \\
Non-essential & Zircon & 2.850 & 0.439 & 6.492 \\
& Niobium & 0.398 & 0.043 & 9.255 \\
& Aluminum & 45.98 & 20.37 & 2.257 \\
& Gold & 0.015 & 0.010 & 1.500 \\
Non metal & Phosphorus & 0.258 & ND & 0.258 \\
& Silicon & 191.2 & 282.1 & 0.677 \\
& Potassium & 1.534 & 2.097 & 0.731 \\
& Rubidium & 0.023 & 0.012 & 1.916 \\
& Thorium & 0.047 & ND & 0.047 \\
\hline
\end{tabular}


Table 8. Pollution load as geo accumulation index ( $\mathrm{I}$ Geo) of farmland soils

\begin{tabular}{ccccc}
\hline Element & Bn & Cm & I geo & Pollution status \\
\hline Aluminum & 8.154 & 45.96 & 2.397 & Moderately contaminated \\
Silicon & 40.513 & 191.2 & 3.713 & Heavily contaminate \\
Calcium & 3.6375 & 0.950 & 0.362 & Uncontaminated \\
Titanium & 22.564 & 8.559 & 2.109 & Moderately contaminated \\
Vanadium & 0.805 & 0.314 & -0.773 & Uncontaminated \\
Chromium & 0.797 & 0.596 & -0.499 & Uncontaminated \\
Manganese & 0.801 & 0.309 & -0.782 & Uncontaminated \\
Iron & 26.03 & 32.62 & 2.753 & Moderately contaminated \\
Nickel & 0.012 & 0.017 & -.3 .866 & Uncontaminated \\
Zinc & 0.168 & 0.046 & -.20288 & Uncontaminated \\
Niobium & 1.496 & 0.398 & -0.401 & Uncontaminated \\
Thorium & 0.093 & 0.047 & -2.537 & Uncontaminated \\
Zircon & 7.536 & 2.850 & 1.155 & Moderately contaminated \\
Phosphorus & 2.034 & 0.258 & -0.456 & Uncontaminated \\
\hline
\end{tabular}

\section{Conclusion}

The results obtained in the mineralogical characterization of Columbite-Tin ore and their vicinity agricultural soil confirm the presence of mineral elements, trace metals and radionuclides in farmland soils around Columbite-Tin mining sites. XRD characterization uncovered the presence of associated minerals, notably braunite, cassiterite, ilmenite, quartz, and zircon in columbite while cassiterite, magnetite and litharge were traced in tin mineral. The chemical composition indicates that the over eighteen (18) stable and radioactive elements present in the mineral ores were also found in the vicinity agricultural soil. Both the geo-accumulation and contamination factor indices present some level of pollution. These elements were linked to different forms of soil deconditioning. Of great concern is the presence of Radionuclides K-40, Rubidium and Thorium in the soil. The contamination of this soil by radionuclides and other heavy metals could lead to a negative influence on soil characteristics and limits production and environmental functions. From the highlights of this research, it is recommended that mining operations should be carried out under strict environmental laws and regulations to forestall agricultural farmlands contamination and the introduction of safe mining practices coupled with advanced technology are needful for heath consideration and exploitation of associated minerals respectively.

\section{ORCID}

\section{A.U. Itodo (iD): 0000-0002-4755-2270}

\section{References}

[1]. S.U. Onwuka, J.O. Duluora, C.O. Okoye, 
Int. j. Eng. Sci. invent., 2013, 2, 30-34.

[2]. A.O. Adegbulugbe, Int. J. Eng. Sci. Invent., 2007, 2, $2319-6734$.

[3]. S.S. Ahluwalia, D. Goyal, Biores. Technol. J., 2007, 98, 2243-2257.

[4]. S.J. Mallo, the Nigerian Mining Journal, 1999, 3, 1-2.

[5]. M.A. Adeniran, E. Ekpo , O.A, Adedayo, V.J, Ibekwe, case study of Jos metropolis, Plateau state, Nigeria. 2013, 1, 1-3

[6]. M. Klementova, M. Rieder, Z. Weiss, J. GEOsci. 2000, 45, 155-157.

[7]. M. Ahmedna, W.E. Marshall, R.M. Rao, Biores. Technol., 2000, 71, 113-123.

[8]. E.E. Ntekim, S.J. Ekwere, E.E. Ukpong, Environ. Geol., 2015, 4, 237-241.

[9]. W. Wang, G. Yang, I.A. Pablo, L. Anxin, Geomorphorlogy, 2015, 1, 1-7

[10]. J.L. Schroeder, N.T. Basta, S.W. Casteel, T. Evans, T.J. Payton, J. Si, J. Environ. Quality, 2004, 33:513-521.

[11]. P.W. Abraham, Sci. Total Environ., 2002, 29, 1, 1-32

[12]. H.U. Itodo, L.A. Nnamonu, R.A. Wuana, Asian J. Chem. Sci. 2017, 3, 1-10.

[13]. N.N. Jibiri, I.P. Farai, I.S.K. Alausa, Int. J. Soil, Sediment and Water, 2007, 2, 7-10.

[14]. V. Sheoran, A.S. Sheoran, P. Poonia, Int. J. Miner. Process., 2010, 6, 1-19.

[15]. P. Koorevaar, G. Menelik, C. Dirksen, Elements of soil physics (vol.13), Elsevier, 1983, pp. 1-12.

[16]. S.K. Maiti, M.K. Ghose, Nigeria, J. Radiol.
Prot., 2005, 28, 93-99.

[17]. A.I. Pozdnyakova, L.A. Pozdnyaakova, J. Environ. Sci., 2002, 7, 14-21.

[18]. M. Ogwuegbu, G. Onyedika, J.Y. Hwang, A. Ayuk, Z. Peng, B. Li, E.N.O. Ejike, M. Andriese, J. Miner. Mater. Characterizat. Eng., 2011, 10, 855-863.

[19]. A. Ayeshamariam, C. Sanjeeviraja, R.P. Samy, J. Photon. Spintron., 2013, 2, 4-9.

[20]. N.J. Cook, Norg. Geol. Unders. B., 2000, 438,189-192.

[21]. P. Patra, K.A. Natarajan, J. Coll. interface Sci., 2006, 298, 720 - 729.

[22]. P.K. Sharma, R.K. Hanumantha. Miner. Metal. Process. 2005, 22, 31.

[23]. D.G. Thomas, F. Asuke, S.A. Yaro, Proceedings of the Nigeria Engineering Conference, Faculty of Engineering, 2014, 827-841.

[24]. E.A. Casartelli, N. Miekeley, Anal. Biol. Chem. J., 2003, 377, 58-64.

[25]. C. Peng, Y. Ma, Y. Ding, X. He, P. Zhang, T. Lan, D. Wang, Z. Zhang, Z. Zhang, Int. J. Mol. Sci., 2017, 18, 795.

[26]. B.E. Allred, P.B. Rupert, S.S. Gauny, D.D. An, C.Y. Ralston, M. Sturzbecher-Hoehne, R.K. Strong, R.J. Abergel, Proc Natl Acad Sci U $S$ A., 2015, 112, 10342

[27]. M.S. Chanada, N.G. Obaje, A. Moumouni, N.G. Goki, U.A. Lar, Online J. Earth Sci., 2010, 4, 38-42.

[28]. K. Pollard, C. Rickaby, M. Miers, Health Sciences and Practice, 2008, 77-78. 
[29]. O. Zmora, D.J. Grosse, N. Zou, T.M. Samocha, Microalgae for aquaculture: practical implications. Handbook of microalgal culture. Wiley, Chichester, 2013, pp. 628-652.

[30]. S. Britto, S. Joseph, P.V. Kamath, J. Chem.

Sci., 2010, 122, 751-756 [31]. M. Roy, C.D. Hirak, Neues Jahrb. 478.
[32]. B. Yang, X. Zhong, X. Zhang, J. Jia, G. Yi, Particuol. J., 2012, 10, 365-370.

[33]. G. Du, C. Zhong, P. Zhang, Z. Guo, Z. Chen, H. Liu, Electrochim. Acta, 2010, 55, 2582-2586.

[34]. T. Inada, A. Kasai, K. Nakano, S. Komatsu, A. Ogawa, ISIJ Int., 2009, 49, 470-

Mineral, 1981, 142,149-160.

How to cite this manuscript: Adams Udoji Itodo*, Raymond Ahulle Wuana, Bulus Emmanuel Duwongs, Davoe Danbok Bwede, Mineralogy and Pollution Status of Columbite-Tin Ore Contaminated Soil, Adv. J. Chem. A, 2019, 2(2), 147-164. 